\title{
Presence and Some Characteristics of Peroxisomes in Immortalized Human Trophoblast Cells
}

\author{
Fumie Hashimoto, ${ }^{*, a}$ Shigeta Shimooka, ${ }^{a}$ Kaori Imasaki, ${ }^{a}$ Asuka Ono, ${ }^{a}$ Maiko Kumaoka,,${ }^{a}$ \\ Sadaki YокотA, ${ }^{b}$ Satoru TAKedA, ${ }^{c}$ Masaki OKaWARA,${ }^{a}$ and Hidenori HAYASH ${ }^{a}$ \\ ${ }^{a}$ Faculty of Pharmaceutical Sciences, Josai University; Keyakidai, Sakado, Saitama 350-0295, Japan: ${ }^{b}$ Section of \\ Functional Morphology, Faculty of Pharmaecutical Science, Nagasaki International University; Sasebo, Nagasaki 859- \\ 3298, Japan: and ${ }^{c}$ Department of Obstetrics and Gynecology, Saitama Medical Center, Saitama Medical School; \\ Kawagoe, Saitama 350-8550, Japan. Received October 11, 2007; accepted January 28, 2008; published online 29, 2008
}

Using morphological and biochemical (Western blot and cell fractionation) methods, we investigated whether peroxisomes are present in human extravillous trophoblast cells. Immortalized extravillous trophoblast cells (TCL-1) were incubated in the presence or absence of $0.5 \mathrm{~mm}$ clofibric acid for $3 \mathrm{~d}$. In immunofluorescence staining of trophoblast cells with antibodies anti-catalase and anti-acyl-CoA oxidase (marker enzymes of peroxisomes), electron microscopy and immunoelectron microscopy, peroxisomes were detected in the cells. The size and number of peroxisomes in the trophoblast cells were smaller than those in rat liver. The number of peroxisomes was increased by clofibric acid. In Western blot experiment with antibodies anti-peroxisomal enzymes of $\beta$-oxidation system, densitometric analysis revealed approximately two fold increase in staining by clofibric acid. When we performed cell fractionation experiment using catalase as one of the peroxisomal marker enzymes, the highest activity of catalase was found in the light mitochondrial fraction. Specific activity of catalase in the light mitochondrial fraction was significantly increased to about 1.3 times higher than the control value by clofibric acid treatment. Upon Nycodenz density gradient centrifugation, the catalase activity was concentrated in the density fraction around 1.14-1.15. These findings suggest that microperoxisomes, which have a density smaller than those of rat hepatic peroxisomes, do exist in human extravillous trophoblast cells. It may also be possible to proliferate human peroxisomes in limited quantities using peroxisome proliferator of rodents.

Key words peroxisome; trophoblast; clofibric acid; catalase

Reports about the peroxisomes of rat liver are abundant, ${ }^{1-16)}$ but much less is known about those of other rat organs. ${ }^{17,18)}$ Furthermore, there are few reports about peroxisomes of human liver, ${ }^{2,3,5,6,8-10,14,19)}$ and very few about those of other human organs. ${ }^{20-22)}$

There are three kinds of trophoblasts in the placenta: cytotrophoblasts, syncytiotrophoblasts and extravillous trophoblasts. Each of the three plays important roles in the development and maintenance of gestation. In human trophoblasts, peroxisomes are known to be present in cytotrophoblast cells, ${ }^{20,22)}$ and are detected later during gestation in syncytiotrophoblast cells. ${ }^{22}$ However, extravillous trophoblast cells are difficult to obtain; therefore peroxisomes in these cells have not yet been elucidated.

Clofibric acid (a fibric acid derivative) is a hypolipidemic agent. This agent, at least, is thought to suppress the synthesis of cholesterol by inhibiting 3-hydroxy-3-methylglutarylCoA reductase (HMG-CoA reductase), the rate-limiting enzyme of cholesterol synthesis in the whole body ${ }^{23,24)}$ and cell cultures. ${ }^{13)}$ We previously reported the effects of clofibrate and gemfibrozil (one of the fibric acid derivatives) on the synthesis of isoprenoid lipids such as ubiquinone, dolichol and cholesterol in the whole body and cultured cells of rats. $^{13,15,25)}$

Almost all of the hormone-producing cells secrete either steroid hormone or protein hormone, but trophoblast cells secrete both. We previously reported that clofibric acid and gemfibrozil up-regulate progesterone (steroid hormone) secretions in human extravillous trophoblast cells using an immortalized trophoblast cell-line (TCL-1). ${ }^{26,27)}$ That is, clofibric acid and gemfibrozil activated steroid hormone synthesis although these substances are inhibitors of HMG-CoA reduc- tase. Steroid hormone is synthesized from cholesterol. Peroxisomes take part in cholesterol synthesis. ${ }^{28)}$ Sterol carrier protein 2 may participate in steroid hormone synthesis, ${ }^{29-31)}$ and is reported to be primarily localized in peroxisomes. ${ }^{32-34)}$

We detected catalase and fatty acyl-CoA oxidase activity in the homogenate of TCL-1 cells, ${ }^{27}$ ) but whether peroxisomes are present in the cells has not been clarified. Therefore, using morphological and biochemical (cell fractionation) techniques, we studied the presence of peroxisomes in these extravillous trophoblast cells.

Clofibrate is not only a hypolipidemic agent, but also a peroxisome proliferator-activated receptor $\alpha$ (PPAR $\alpha$ ) agonist in rodents. With respect to the effect of PPAR $\alpha$ agonist on peroxisomal enzymes and proliferation, there are many reports about rat liver. ${ }^{1-16)}$ In human liver cells, some reports demonstrated an increase in peroxisomal enzyme activity caused by PPAR $\alpha$ agonist, $, 5,6,10,12,19)$ while others reported that there was no effect. ${ }^{2,3,8,9,14)}$ In all organs except the liver, the effects of PPAR agonist on peroxisomes are little reported in rats, ${ }^{17)}$ and even less so in humans. ${ }^{21)}$ Therefore, we also studied the effect of clofibric acid on extravillous trophoblast cells. As a result, we clarified the presence of peroxisomes in human extravillous trophoblast cells and defined some characteristics of these peroxisomes, including changes in peroxisomes after treatment with clofibric acid.

\section{MATERIALS AND METHODS}

Materials Clofibric acid, Triton X-100, fish gelatin, phenylmethylsulfonyl fluoride, cytochrome $c$ and fetal calf serum were obtained from Sigma-Aldrich Japan (Tokyo, Japan). Leupeptin, chymostatin, pepstatin and bestatin were 
purchased from Peptide Institute (Osaka, Japan). RPMI 1640 medium was purchased from Nissui Chemicals (Tokyo, Japan). Diaminobenzidine tetrahydrochloride (DAB) was obtained from Dojin Chemicals (Kumamoto, Japan). Guinea pig anti-rat catalase and rabbit anti-rat acyl-CoA oxidase were the same lots as described previously. ${ }^{35,36)}$ Alexa ${ }^{\circledR}$ 549iconjugated goat anti-guinea pig IgG and FITC-labeled swine anti-rabbit IgG were purchased from Invitrogen Corporation (Carlsbad, CA, U.S.A.) and DAKO Japan (Tokyo, Japan), respectively. LRWhite resin was obtained from London Resin Company (Basingstoke, U.K.). All other reagents were of analytical grade and were purchased from Wako Pure Chemicals (Osaka, Japan).

Culture of Trophoblast Cells and Drug Treatment The trophoblast cell line-1 (TCL-1) was obtained by immortalizing third-trimester human trophoblast with the large-T antigen from the SV40 virus, as described in detail elsewhere. ${ }^{26)}$ The cells in RPMI 1640 medium (12 ml) containing $2 \mathrm{~mm}$ glutamine, $0.2 \%$ gentamycin sulfate, and $10 \%$ fetal bovine serum (FBS) were plated on plastic plates $(100 \mathrm{~mm}$ diameter) at $10^{5}$ cells $/ \mathrm{ml}$ and then cultured at $37^{\circ} \mathrm{C}$. The medium was changed $24 \mathrm{~h}$ after plating. Drug treatment was initiated $24 \mathrm{~h}$ after plating by changing the medium to that containing the drug, and thereafter the medium was changed every $24 \mathrm{~h}$ until $3 \mathrm{~d}$. Clofibric acid solubilized in ethanol was added. The final concentration of ethanol was $0.2 \%(\mathrm{v} / \mathrm{v})$. Ethanol was also added to the medium in the control cells. During the last $24 \mathrm{~h}$ of the culture, the medium was removed. The attached cells were washed with phosphate-buffered saline (PBS).

Immunofluorescence Staining Cultured cells that were washed 3 times with PBS were fixed with 4\% paraformaldehyde in $0.15 \mathrm{~m}$ HEPES/KOH (pH 7.4) for $15 \mathrm{~min}$ at room temperature. After 3 washes with $\mathrm{PBS}$, fixed cells were treated with $0.1 \%$ Triton $\mathrm{X}-100-\mathrm{PBS}$ for $15 \mathrm{~min}$ at room temperature, followed by $1 \mathrm{~h}$-incubation with $2 \%$ fish gelatinPBS to block nonspecific IgG absorption to the cells. The cells were then incubated with primary antibodies such as guinea pig anti-rat catalase and rabbit anti-rat acyl-CoA oxidase overnight at $4^{\circ} \mathrm{C}$. After 3 washes with PBS for 5 min to each, the cells were incubated with Alexa 549i-conjugated goat anti-guinea pig or FITC-labeled swine anti-rabbit IgG for $1 \mathrm{~h}$ at room temperature. The primary antibodies used were diluted 1000-fold and the secondary antibodies 200- to 2000 -fold. The cells were mounted using 70\% glycerol-PBS and observed with a Y-FL Nikon fluorescent microscope (Nikon, Tokyo, Japan).

Routine Electron Microscopy Cells washed with PBS were fixed with $1 \%$ glutaraldehyde in $0.1 \mathrm{~m} \mathrm{HEPES} / \mathrm{KOH}$ $(\mathrm{pH} 7.4)$ for $1 \mathrm{~h}$ at room temperature. Cells were washed 3 times with PBS, and removed from the dishes using a rubber policeman with $10 \%$ ethanol-PBS. Cells were collected by centrifugation $(6000 \mathrm{rpm}, 1 \mathrm{~h}$, room temperature), and $10 \%$ ethanol-PBS were then removed. After the addition of low melting agarose, cells were immediately centrifuged. Cells quenched in low melting agarose were cut into approximately $1 \mathrm{~mm}^{3}$ and post-fixed in reduced $1 \%$ osmium tetroxide for $1 \mathrm{~h}$ at room temperature. The cells were then dehydrated through a graded ethanol series $(50,70,80,90,100 \%)$ for $15 \mathrm{~min}$ each, and embedded in Epon 812. Epoxy resin was polymerized for $24 \mathrm{~h}$ at $60^{\circ} \mathrm{C}$. Ultrathin sections were cut by a dia- mond knife using a Reichert Ultracut R (Leica, Wienna, Austria) and mounted on copper grids. The sections were then double stained with $2 \%$ uranyl acetate for $10 \mathrm{~min}$ and lead citrate $5 \mathrm{~min}$.

Cytochemical Staining of Catalase Cells were fixed with $1 \%$ glutaraldehyde in $0.1 \mathrm{M} \mathrm{HEPES} / \mathrm{KOH}(\mathrm{pH} 7.4)$ for $1 \mathrm{~h}$ at room temperature. The fixed cells were washed 3 times with PBS, and incubated in DAB reaction medium consisting of 3,3'-diaminobenzidine tetrahydrochloride $(2 \mathrm{mg} / \mathrm{ml})+$ $0.02 \%$ hydrogen peroxide $+0.05 \mathrm{M}$ glycine- $\mathrm{NaOH}$ buffer $(\mathrm{pH}$ 10.0 ) for $1 \mathrm{~h}$ at room temperature. After briefly washing in PBS, cells were collected in agarose and osmificated with $1 \%$ reduced osmium tetroxide for $1 \mathrm{~h}$ at room temperature. Cells were then processed to electron microscopic procedures.

Immunoelectron Microscopy Cells were fixed with 4\% paraformaldehyde and $0.25 \%$ glutaraldehyde in $0.15 \mathrm{M}$ HEPES/KOH ( $\mathrm{pH} 7.4$ ) for $30 \mathrm{~min}$ at room temperature. Cells were washed 3 times with PBS, and removed from the dishes using a rubber policeman with $10 \%$ ethanol-PBS. Cells were collected by centrifugation, and $10 \%$ ethanol-PBS were then removed. After the addition of low melting agarose, cells were immediately centrifuged. Cells quenched in agarose were dehydrated as described above at $-20^{\circ} \mathrm{C}$ and embedded in LRWhite resin. The resin was polymerized overnight at $-20{ }^{\circ} \mathrm{C}$ under UV light. Ultrathin sections were cut by a diamond knife using an ultramicrotome as described above and mounted on nickel grids. The sections were treated with $2 \%$ fish gelatin-PBS for 10 min and then incubated with rabbit anti-rat acyl-CoA oxidase antibody overnight at $4{ }^{\circ} \mathrm{C}$. After washing with PBS, the sections were incubated with protein A-gold probe $(10 \mathrm{~nm}$ gold particles) for $30 \mathrm{~min}$ at room temperature. Then the sections were washed with ultrapure water and dried in air, followed by electron staining with $2 \%$ uranyl acetate for $10 \mathrm{~min}$ and lead citrate for $30 \mathrm{~min}$. After drying, the sections were coated with carbon.

All thin sections were observed with Hitachi H7500 electron microscope (Hitachi, Tokyo, Japan) at an accelerating voltage of $80 \mathrm{kV}$.

Immunoblot Analysis Cell pellets were homogenized with approximately 10 times its volume of $50 \mathrm{M}$ Tris- $\mathrm{HCl}$ buffer $(\mathrm{pH} 7.2)$ containing $1 \%$ Triton $\mathrm{X}-100,10 \mu \mathrm{M}$ phenylmethylsulfonyl fluoride, $4 \mu \mathrm{m}$ leupeptin, $4 \mu \mathrm{m}$ chymostatin, $4 \mu \mathrm{m}$ pepstatin and $4 \mu \mathrm{m}$ bestatin. The homogenate was centrifuged at $10000 \times \boldsymbol{g}$ for $30 \mathrm{~min}$. The resulting supernatant was stored at $-70^{\circ} \mathrm{C}$ prior to use. Protein concentrations were determined by the bicinchoninic acid method (Pierce Chemical. Rockford, IL, U.S.A.) using BSA as a standard. Cell extracts were mixed with the same volume of sample buffer for sodium dodecyl sulfate-polyacrylamide gel electrophoresis (SDS-PAGE), and heated at $100^{\circ} \mathrm{C}$ with an aluminum heat block for 5 min. Fifty micrograms of each exract were loaded on a $10 \%$ polyacrylamide gel. SDS-PAGE was performed as described by Laemmli. ${ }^{37)}$ Proteins were transferred to a polyvinylidene fluoride (PVDF) membrane. The membrane was soaked in PBS containing 5\% (w/v) skim milk and incubated with the primary antibodies overnight, followed by the secondary antibodies conjugated with horseradish peroxidase (HRP) for $1 \mathrm{~h}$. Signals were visualized by diaminobenzidine reaction. Rabitt antibodies against rat bifunctional protein and keto-acyl-CoA thiolase were obtained 
from Dr. Hashimoto (Department of Biochemistry, Shinshu University School of Medicine). Mouse monoclonal antibody against actin was obtained from MP Biomedicals (Solon, OH, U.S.A.) Japan. HRP-labeled rabbit anti-mouse IgG was from DAKO Japan.

Densitometry of Western Blot Data Images of blots were entered into a computer using a scanner (GT-8700, Epson, Tokyo, Japan) and analyzed using the software Image-Pro ${ }^{\circledR}$ PLUS (Media Cybernetics, Inc., Silver Spring, MD, U.S.A.).

Method of Homogenization for Cell Fractionation The cells were suspended in $0.25 \mathrm{M}$ sucrose and homogenized by two methods. (1) Teflon homogenizer with a loose Teflon pestle of the Potter-Elvehjem type: The clearance of this homogenizer was about $150 \mu \mathrm{m}$, which is that usually used for rat liver. This homogenizer was termed the "loose Teflon" homogenizer. (2) Teflon homogenizer with a tight Teflon pestle of the Potter-Elvehjem type: The clearance was about 75 $\mu \mathrm{m}$. This homogenizer was termed the "tight Teflon" homogenizer. The cells were carefully homogenized with 4-10 strokes in each homogenizer attached to an electric drill (about $1000 \mathrm{rpm}$ ). After homogenization of the cells, the suspension was first centrifuged at $500 \times \boldsymbol{g}$ for $1 \mathrm{~min}$, and the pellet of unbroken cells was separated. The supernatant was then centrifuged at $105000 \times \boldsymbol{g}$ for $1 \mathrm{~h}$. The resulting pellet was designated the particulate fraction, and the supernatant as the soluble fraction.

Cell Fractionation After separation of unbroken cells, the homogenate of the slime mold cells was fractionated by the method of de Duve et al. ${ }^{38)} \operatorname{Nuclear}(\mathrm{N})$, heavy (M) and light (L) mitochondrial, and microsomal (P) fractions and supernatant (S) were obtained by centrifugation at $600 \times \boldsymbol{g}$ for $10 \mathrm{~min}, 3300 \times \boldsymbol{g}$ for $10 \mathrm{~min}, 12500 \times \boldsymbol{g}$ for $20 \mathrm{~min}$, and $105000 \times \boldsymbol{g}$ for $60 \mathrm{~min}$, respectively.

Nycodenz Density Gradient Centrifugation The cells were homogenized in $0.25 \mathrm{M}$ sucrose containing $5 \mathrm{~mm}$ HEPES (pH 7.4), $1 \mathrm{~mm}$ EDTA and $0.1 \%$ ethanol (SVEH). The light mitochondrial fraction prepared from the homogenate was subjected to Nycodenz density gradient centrifugation. A linear Nycodenz density gradient $(13 \mathrm{ml})$ from density 1.12 to 1.18 was prepared in centrifuge tubes. Next, 2 $\mathrm{ml}$ of the light mitochondrial fraction was layered on top of the gradient. The tubes were centrifuged at $25000 \mathrm{rpm}$ at $4{ }^{\circ} \mathrm{C}$ overnight in a Hitachi model SCP70H ultracentrifuge with a Hitachi RPS27 rotor (Hitachi, Tokyo, Japan). In this centrifugation, a slow acceleration controller, which ensured slow and smooth acceleration up to $1000 \mathrm{rpm}$, was used. After centrifugation, the tubes were divided into 10 fractions of $1.5 \mathrm{ml}$ each from the top of the gradient with an ISCO gradient fractionater (U.S.A.). Each fraction was appropriately diluted with SVEH, and centrifuged at $20000 \times \boldsymbol{g}$ for $30 \mathrm{~min}$. The respective precipitates were suspended in $0.25 \mathrm{M}$ sucrose, and the enzyme activities in each fraction were determined.

Assay of Enzymes and Protein Catalase is a marker enzyme of peroxisomes. Catalase activity was measured according to the method described by Leighton et al. ${ }^{39)}$ with slight modification. ${ }^{40)}$ Cytochrome- $c$ oxidase is a marker enzyme of mitochondria. Its activity was estimated by the method described by Wharton and Tzagoloff ${ }^{41)}$ with a slight modification. ${ }^{42}$ The acid phosphatase activity was determined as a marker enzyme of lysosomes, using the method described previously. ${ }^{40)}$

Protein levels were determined by the Lowry method, using BSA as a standard. ${ }^{43}$ )

\section{RESULTS}

Immunofluorescence Staining Immortalized extravillous trophoblast cells were cultured in the presence or absence of $0.5 \mathrm{~mm}$ clofibric acid for up to $3 \mathrm{~d}$. When anti-rat liver catalase antibody was used for immunofluorescence staining, particles in the trophoblast cells were immunostained, indicating that particles containing catalase were present in the trophoblast cells. After immunofluorescence staining with anti-rat liver fatty acyl-CoA oxidase antibody, particles containing fatty acyl-CoA oxidase were detected the trophoblast cells. "Merged" indicates that the particles contain both catalase and fatty acyl-CoA oxidase. The effect of clofibric acid on the enzymes seems to be obscure in immunofluorescence staining (Fig. 1).

Routine Electron Microscopy and Immunoelectron Microscopy Trophoblast cells were cultured in the presence or absence of $0.5 \mathrm{~mm}$ clofibric acid for up to $3 \mathrm{~d}$. After routine electron microscopy, small granules presumed to be peroxisomes were detected in the trophoblast cells, and were dispersed throughout all areas of the cells. Diameters of peroxisomes were not more than $0.5 \mu \mathrm{m}$. In trophoblast cells treated with clofibric acid, the number of peroxisomes was increased. Regular and irregular forms of peroxisomes were found (Fig. 2).

After cytochemical staining of catalase by DAB, peroxi-
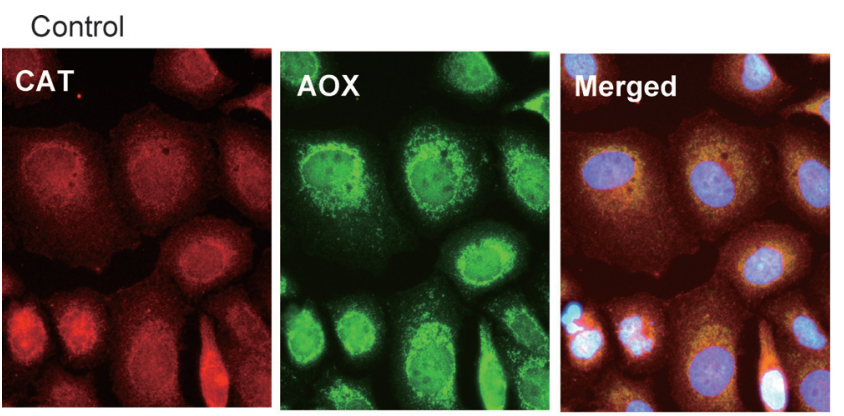

Clofibric acid
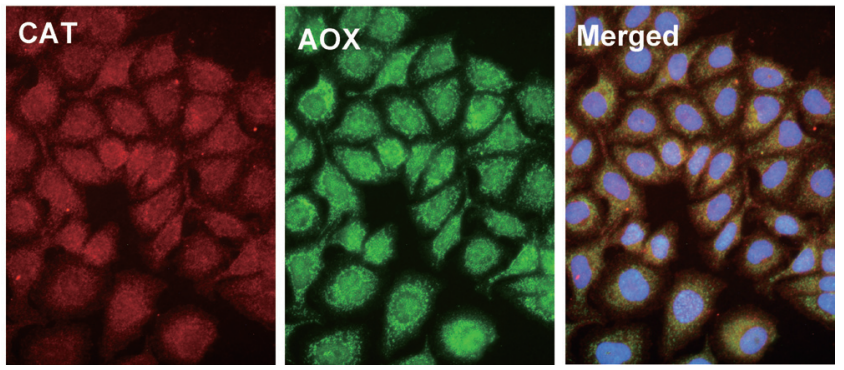

Fig. 1. Immunofluorescence Staining of Immortalized Extravillous Trophoblast Cells

TCL-1 cells were incubated with or without $0.5 \mathrm{~mm}$ clofibric acid for $3 \mathrm{~d}$. Cultured cells were fixed with paraformaldehyde. The cells were then incubated with primary antibodies such as guinea pig anti-rat catalase and rabbit rat acyl-CoA oxidase overnight at $4{ }^{\circ} \mathrm{C}$. After washing, the cells were incubated with Alexa 549i-conjugated goat antiguinea pig IgG or FITC-labeled swine anti-rabbit IgG for $1 \mathrm{~h}$ at room temperature. The cells mounted in 70\% glycerol-PBS were observed with a Y-FL Nikon fluorescent microscope. Control: cells grown in the control culture, $\times 400$. Clofibric acid: cells grown in clofibric acid-containing culture, $\times 200$. CAT: catalase, AOX: acyl-CoA oxidase, Merged: $\mathrm{CAT}+\mathrm{AOX}$ 
Control

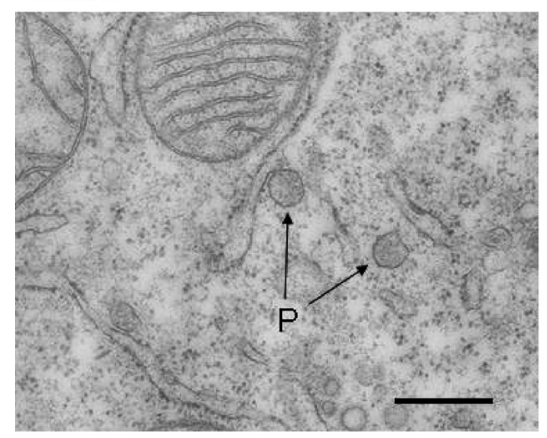

Clofibric acid

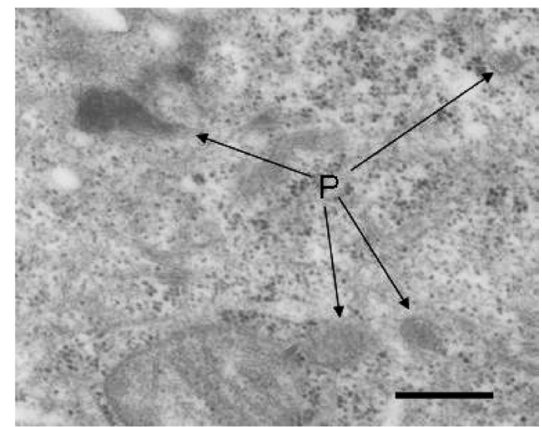

Bar $=0.5 \mu \mathrm{m}$

Fig. 2. Routine Electron Microscopy of Trophoblast Cells

Cells were incubated with or without $0.5 \mathrm{~mm}$ clofibric acid. Washed cells were fixed with glutaraldehyde. The cells were collected by centrifugation, and treated with a low melting agarose. Cells quenched in agarose were cut, and post-fixed in $2 \%$ osmium tetroxide for $1 \mathrm{~h}$ at room temperature. The cells were then dehydrated and embedded in Epon 812 . Ultrathin sections were mounted on copper grids. The sections were then stained doubly with $2 \%$ uranyl acetate for 10 min and lead citrate 5 min. A 11 thin sections were observed with Hitachi H7500 electron microscope. Control: cells grown in the control culture. Clofibric acid: cells grown in clofibric acid-containing culture. Bar, $0.5 \mu$ m. P: peroxisome.

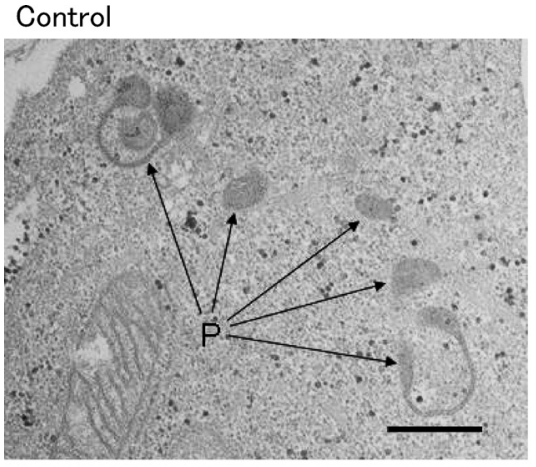

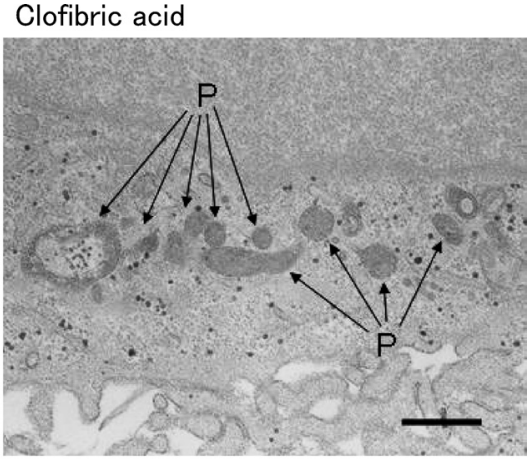

$\operatorname{Bar}=0.5 \mu \mathrm{m}$

Fig. 3. Immunoelectron Microscopy of Trophoblast Cells after DAB Reaction for Catalase

Cells were incubated with or without $0.5 \mathrm{~mm}$ clofibric acid. Washed cells were fixed with glutaraldehyde. The fixed cells were incubated in DAB reaction medium consisting of 3', 3'diaminobenzidine tetrahydrochrolide +hydrogen peroxide + glycine- $\mathrm{NaOH}$ buffer $(\mathrm{pH} \mathrm{10.0)}$ for $1 \mathrm{~h}$ at room temperature. After brief washing, cells were collected in agarose and osmificated with $1 \%$ reduced osmium tetroxide. Cells were then processed by electron microscopic procedures. Control: cells grown in the control culture. Clofibric acid: cells grown in clofibric acid-containing culture. Bar, $0.5 \mu \mathrm{m}$. P: peroxisome.

somes containing catalase were detected in the trophoblast cells. DAB reaction visualizes the peroxidatic activity of catalase in the cells. As shown in Fig. 3, multiple and unusual forms of peroxisomes were found. Multiple forms of peroxisomes such as round, string, ramification and so on were detected in the cells. DAB-staining of the cells treated with clofibric acid demonstrated the increase in the number and catalase content of the peroxisomes (Fig. 3).

When anti-rat liver fatty acyl-CoA oxidase antibody was used for immunoelectron microscopy, peroxisomes in the trophoblast cells were stained, indicating that peroxisomes containing fatty acyl-CoA oxidase were present in trophoblast cells. Treatment of the trophoblast cells with clofibric acid slightly increased the number of the peroxisomes (Fig. 4).

Western Blot Data Antibody to acyl-CoA oxidase developed two bands with molecular mass of 75 and $53 \mathrm{kDa}$ but $22 \mathrm{kDa}$ band was almost invisible. Antibodies to bifunctional protein and to keto-acyl-CoA thiolase showed a single band with $80 \mathrm{kDa}$ and $44 \mathrm{kDa}$, respectively. After treatment with clofibric acid, the bands of acyl-CoA oxidase $(53 \mathrm{kDa}$ band), bifunctional protein and keto-acyl-CoA thiolase demonstrated 1.8, 1.9 and 1.9-fold increases in staining, respectively (Fig. 5). After the treatment, $75 \mathrm{kDa}$ band of acyl-
CoA oxidase also demonstrated 1.8-fold increase in staining (data not shown). The results show that clofibric acid treatment increases in $\beta$-oxidation enzymes.

Disruption of Trophoblast Cells To confirm the morphological data, we performed biochemical experiments. We used catalase as a peroxisomal marker enzyme in these experiments. Since the activity of catalase is higher than that of other enzymes in peroxisomes, we can easily obtain significant data even when low activity was detected. Methods for disruption of the cells are extremely important for the study of cytoplasmic particles. Figure 6 compares two homogenizing methods for obtaining peroxisomes of trophoblast cells. Of these methods, the usual "loose Teflon" homogenizer could not disrupt the cells under the conditions described in the legend. The best method of homogenization for obtaining peroxisomes was a Teflon homogenizer using a pestle with a very small clearance. By this method, approximately $84 \%$ of the total catalase existing in the broken cells was detected in the particle fraction.

Cell Fractionation Trophoblast cells were cultured in the presence or absence of $0.5 \mathrm{~mm}$ clofibric acid for up to $3 \mathrm{~d}$. After disruption of the cells by the "tight Teflon" homogenizer, the homogenate was fractionated according to the 
Control

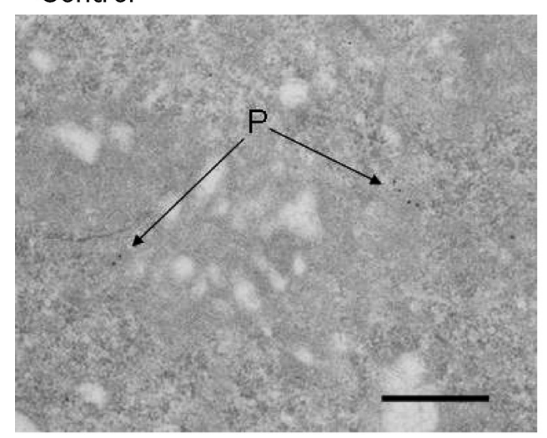

Clofibric acid

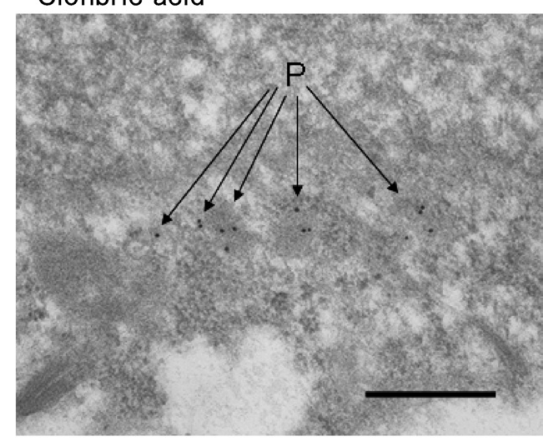

$\operatorname{Bar}=0.5 \mu \mathrm{m}$

Fig. 4. Electron Micrograph of Trophoblast Cells after Reaction with Antibody for Fatty Acyl-CoA Oxidase

Cells were incubated with or without $0.5 \mathrm{~mm}$ clofibric acid. Washed cells were fixed with paraformaldehyde and glutaraldehyde. Cells quenched in agarose were cut and dehydrated at $-20^{\circ} \mathrm{C}$, and embedded in LRWhite resin. Utrathin sections were treated with fish gelatin-PBS and then incubated overnight with rabbit anti-rat acyl-CoA oxidase antibody at $4{ }^{\circ} \mathrm{C}$. After washing, the sections were incubated with protein A-gold probe $(10 \mathrm{~nm}$ gold particles) for 30 min at room temperature. Then the sections were washed and dried, followed by electron staining with $2 \%$ uranyl acetate for $10 \mathrm{~min}$ and lead citrate for $30 \mathrm{~min}$. After drying, the sections were coated with carbon. Control: cells grown in the control culture. Clofibric acid: cells grown in clofibric acid-containing culture. Bar, $0.5 \mu \mathrm{m}$. P: peroxisome.

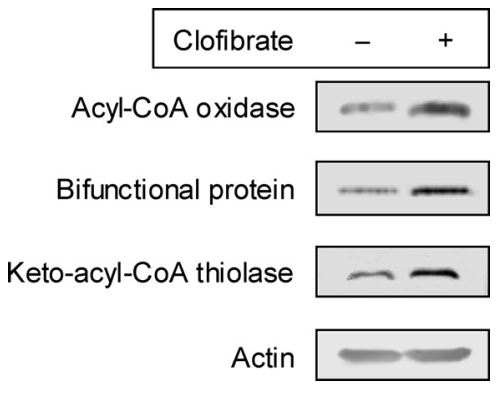

Fig. 5. Western Blotting of Triton X-100 Extracts from Cells Treated with or without Clofibric Acid

Results of acyl-CoA oxidase were obtained from $53 \mathrm{kDa}$ band.

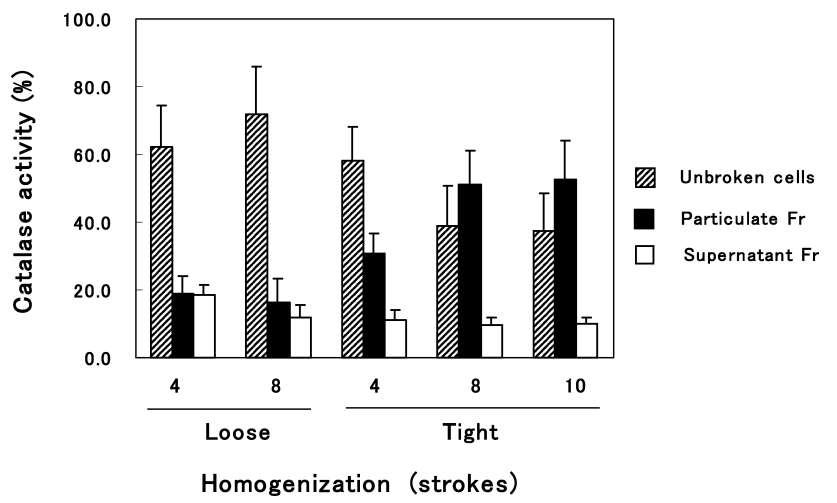

Fig. 6. Effects of Homogenization Conditions of Trophoblast Cells Using a Teflon Homogenizer on the Distribution of Catalase Activity

Trophoblast cell line-1 (TCL-1) cells were homogenized by loose (clearance: $150 \mu \mathrm{m})$ or tight $(75 \mu \mathrm{m})$ type of Teflon homogenizer. The homogenate suspensions were first centrifuged at $500 \times \boldsymbol{g}$ for $1 \mathrm{~min}$, and the pellets (unbroken cells) were obtained. The supernatants were then centrifuged at $105000 \times \boldsymbol{g}$ for $1 \mathrm{~h}$. The resulting pellets (particulate fraction) and supernatants were obtained. The catalase activities of each fraction were determined. Data are means \pm S.D. of 3 experiments.

method described by de Duve et al. ${ }^{38)}$ Catalase activities were highly concentrated in the light mitochondrial fraction, about $45 \%$ of the total catalase being found in that fraction. The most concentrated activity of acid phosphatase as a marker enzyme of lysosomes appeared in the light mitochondrial fraction. Approximately $44 \%$ of the total activity of acid phosphatase existed in that fraction. The most concentrated activity of cytochrome- $c$ oxidase as a marker enzyme of mitochondria appeared in the heavy mitochondrial fraction (Fig. 7).

Table 1 shows a comparison of the distribution of catalase activity in cell fractionation between TCL-1 cells and rat liver. ${ }^{11)}$ Smaller peroxisomes were detected in TCL-1 cells. Clofibric acid hardly affected the size of peroxisomes.

Table 2 shows specific activity of catalase in homogenate and light mitochondrial fraction of trophoblast cells cultured in the presence or absence of $0.5 \mathrm{~mm}$ clofibric acid for up to $3 \mathrm{~d}$. Specific activities in the homogenate and the light mitochondrial fraction were increased about 1.2 and 1.3 times, respectively, by the administration of clofibric acid. This increase rate was similar to that in rat liver. ${ }^{44)}$

Nycodenz Density Gradient Centrifugation To separate peroxisomes and lysosomes, we performed Nycodenz gradient centrifugation of the light mitochondrial fraction. The highest peak of catalase activities was found in the density fraction of $1.14-1.15 \mathrm{~g} / \mathrm{ml}$, and moderate levels of these activities of these also appeared in the density fraction around $1.14-1.15 \mathrm{~g} / \mathrm{ml}$. The patterns of catalase differed from those of acid phosphatase. The density of lysosomes was $1.125-1.130$. Clofibrate increased the catalase activity and protein content of the peroxisomal fraction from trophoblast cells (Fig. 8).

\section{DISCUSSION}

From the results of light and electron microscopy, it was clarified that peroxisomes do exist in extravillous trophoblast cells (Figs. 1-4). Many various and irregular forms of peroxisomes were present in the cells. ${ }^{45,46}$ ) The size of peroxisomes in trophoblast cells was smaller than that in rat liver. ${ }^{44)}$ Namely, microperoxisomes exist in trophoblast cells (Figs. 2 -4). ${ }^{47}$ The microperoxisomes were confirmed by biochemical methods such as the homogenization experiment (Fig. 6) and cell fractionation (Fig. 7, Table 1). The number of peroxisomes in trophoblast cells was smaller than that in rat liver (Figs. 2-4). ${ }^{44)}$ The number of peroxisomes in trophoblast cells was similar to that in rat intestine. ${ }^{47}$

From the preceding and present studies, trophoblast perox- 
Catalase

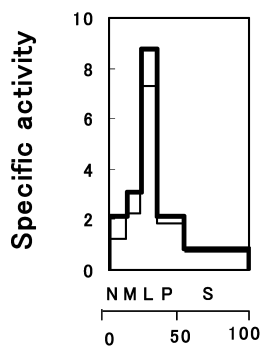

Acid phosphatase

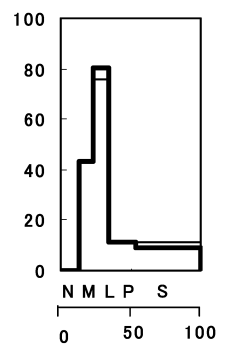

Protein (\%)
Cyt- $c$ oxidase

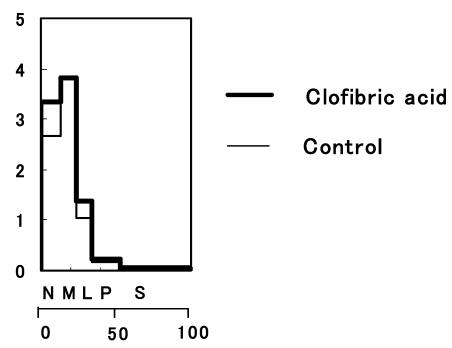

Fig. 7. Patterns of Distribution of Enzyme Activity in the Subcellular Fraction of TCL-1 Cell Homogenate

TCL-1 cells were incubated with (-) or without (-) $0.5 \mathrm{~mm}$ clofibric acid for $3 \mathrm{~d}$. Homogenates of TCL-1 cells were fractionated according to the method of de Duve et al. ${ }^{38)}$ The ordinate represents the specific activity of marker enzymes: catalase (peroxisomal marker), acid phosphatase (lysosomal marker), cytochrome- $c$ oxidase (mitochondrial marker). The abscissa represents the protein content relative to the total. N, nuclear fraction; M, mitochondrial fraction; L, light mitochondrial fraction; P, microsomal fraction; S, cytosol fraction.

Table 1 Comparison of Distribution of Catalase Activity in Cell Fractionation between TCL-1 Cells and Rat Liver

\begin{tabular}{lccccc}
\hline \hline & \multicolumn{2}{c}{$\begin{array}{c}\text { Large peroxisomes } \\
\text { M/L ratio }\end{array}$} & & \multicolumn{2}{c}{$\begin{array}{c}\text { Small peroxisomes } \\
\text { P/L ratio }\end{array}$} \\
\cline { 2 - 3 } \cline { 5 - 6 } & Control & Clofibric acid & & Control & Clofibric acid \\
\cline { 5 - 6 } TCL-1 cells & 0.31 & 0.36 & & 0.43 & 0.46 \\
Rat liver & 0.60 & $-a)$ & & 0.19 & $-a)$ \\
\hline
\end{tabular}

a) Not revealed in the report. ${ }^{11)}$ Ratio of $\mathrm{M} / \mathrm{L}$ and that of $\mathrm{P} / \mathrm{L}$ were calculated from data shown in Fig. 7. M: catalase activity in the mitochodrial fraction, L: catalase activity in the light mithochondrial fraction, P: catalase activity in the microsomal fraction, (rat liver: Biol. Pharm. Bull., 20, 315-321 (1997)).
Table 2 Effect of Clofibric Acid on Specific Activity of Catalase of TCL-1 Cells

\begin{tabular}{lccc}
\hline \hline & \multicolumn{2}{c}{$\begin{array}{c}\text { Catalase specific activity } \\
(\mathrm{u} / \mathrm{mg} \text { protein })\end{array}$} & \\
\cline { 2 - 3 } & \multicolumn{2}{c}{$\mathrm{T} / \mathrm{C}$} \\
& Clofibric acid (T) & Control (C) & \\
\hline Homogenate & $2.04 \pm 0.32$ & $1.66 \pm 0.21$ & $1.23^{*}$ \\
Light mitochondrial fraction & $8.90 \pm 2.22$ & $6.86 \pm 1.71$ & $1.30^{*}$ \\
\hline
\end{tabular}

After treatment with $0.5 \mathrm{~mm}$ clofibric acid for $3 \mathrm{~d}$, TCL-1 cells were collected and homogenized. The light mitochondrial fraction was prepared from the homogenate and catalase activity and protein content were then assayed. Data are mean values \pm S.D. of 6 - 8 experiments. * Represents significant changes $(p<0.05)$.
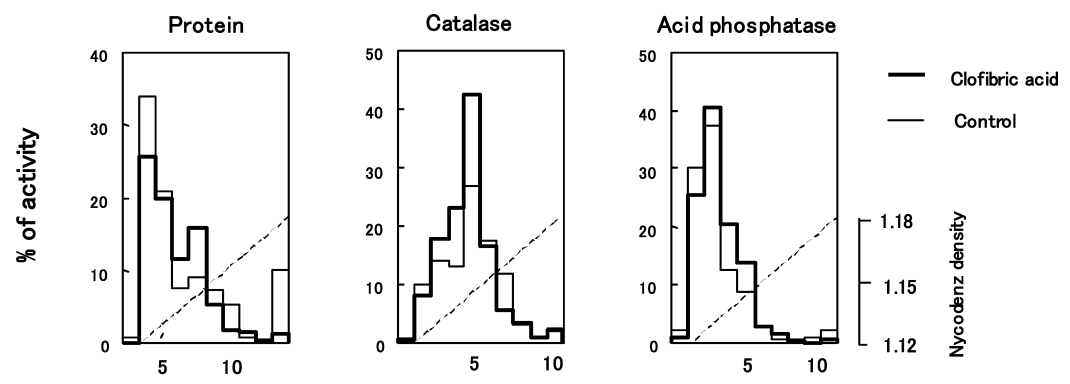

Fraction No.

Fig. 8. Patterns of Distribution of Enzyme Activity and Protein Content in Nycodenz Density Gradient Centrifugation of the Light Mitochondrial Fraction of TCL-1 Cells

TCL-1 cells were treated with (-) or without (-) $0.5 \mathrm{~mm}$ clofibric acid for $3 \mathrm{~d}$. The light mitochondrial fraction was prepared from TCL-1 cell homogenate, and subjected to Nycodenz density gradient centrifugation. The ordinates represent the enzyme activity or protein content of the fractions relative to the total activity of L fractions. The abscissa represents fraction numbers from the top of the tube.

isomes may contain catalase and fatty acyl-CoA oxidase. ${ }^{27)}$ After immunofluorescence staining with both anti-catalase antibody and anti-fatty acyl-CoA oxidase antibody, "Merged" indicates that red staining of catalase was detected in the cytoplasm (Fig. 1 A-3), indicating that catalase is also present in cytoplasm before transportation of the enzyme into peroxisomal particles.

As shown in morphological data (Figs. 2-4), the number of peroxisomes was increased by $0.5 \mathrm{~mm}$ clofibric acid, indicating that clofibric acid induces peroxisomes in trophoblast cells. Because the peroxisomes were dispersed throughout the cells, we could not determine an absolute rate of increase in the number following exposure to clofibric acid. Effects of clofibric acid were confirmed by the biochemical data of Western blot (Fig. 5) and catalase activity in the light mitochondrial fraction (Table 2). In human liver cells, some reports indicate an increase $(1-2$ fold) in peroxisomal enzyme activity by peroxisomal proiliferators, ${ }^{5,6,10,12,19)}$ but other reports do not. ${ }^{2,3,8,9,14)}$ Thus, our data of human extravillous trophoblast cells support the former findings.

The density of peroxisomes in TCL-1 cells (1.14-1.15 $\mathrm{g} / \mathrm{ml})$ seemed smaller than that in rat liver $\left.(\mathrm{d}=1.19-1.20) .{ }^{11}\right)$ The catalase activity and protein content of the peroxisomal fraction from trophoblast cells were also increased by clofibric acid on density gradient centrifugation (Fig. 8).

In conclusion, it was clarified that peroxisomes do exist in 
human extravillous trophoblast cells. Peroxisomes in trophoblast cells differ from those in rat liver with respect to size, density and number. The trophoblast cells secrete either steroid hormone or protein hormone. We recently reported that PPAR $\alpha$ agonists, clofibrate and gemfibrozil down-regulate human chorionic gonadotropin (hCG) (protein hormone) and up-regulate progesterone (steroid hormone) secretions in human extravillous trophoblast cells. ${ }^{27,38)}$ Steroid hormone is synthesized from cholesterol. Peroxisomes take part in the synthesis of cholesterol from which steroid hormone is synthesized. ${ }^{28)}$ Sterol carrier protein 2 may participate in steroid hormone synthesis, ${ }^{29-31)}$ and is reported to be primarily localized in peroxisomes. ${ }^{32-34,48)}$ It is reported that many data pointed out the important role of peroxisomes in steroidogenesis. ${ }^{49-51)}$ In the present study, clofibrate, rodent peroxisome proliferator may proliferate peroxisomes of human trophoblast cells to a lesser extent. Therefore, immortalized human trophoblast cells (TCL-1) seem to be useful for investigating the participation of microperoxisomes of human trophoblast cells in functions such as steroidgenesis.

\section{REFERENCES}

1) Butterworth B. E., Smith-Oliver T., Earle L., Loury D. J., White R. D., Doolittle D. J., Working P. K., Cattley R. C., Jirtle R., Michalopoulos G., Strom S., Cancer Res., 49, 1075-1084 (1989).

2) Bichet N., Cahard D., Fabre G., Remandet B., Gouy D., Cano J.-P., Toxcol. Appl. Pharmacol., 106, 509-517 (1990).

3) Blaauboer B. J., van Holsteijn C. W. M., Bleumink R., Mennes W. C., van Pert F. N., Yap S. H., van Pelt J. F., van Iersel A. A. J., Biochem. Pharmacol., 40, 521-528 (1990).

4) Osumi T., Yokota S., Hashimoto T., J. Biochem. (Tokyo), 108, 614 621 (1990).

5) Brocard C., E.-Souni M., Ramirez L. C., Latruffe N., Bournot P., Biol. Cell, 77, 37-41 (1993).

6) Scotto C., Keller J. M., Schohn H., Dauca M., Eur. J. Cell Biol., 66, 375-381 (1995)

7) Hashimoto F., Ishikawa T., Hamada S., Hayashi H., Biochem. Pharmacol., 49, 1213-1221 (1995).

8) Richert L., Price S., Chesne C., Maita K., Calmichael N., Toxicol. Appl. Pharmacol., 141, 35-43 (1996).

9) Elcombe C. R., Bell D. R., Elias E., Hasmall S. C., Plant N. J., Ann. N.Y. Acad. Sci., 804, 628-635 (1996).

10) Duclos S., Bride J., Ramirez L. C., Bournot P., Eur. J. Cell Biol., 72, 314-323 (1997).

11) Hashimoto F., Hamada S., Hayashi H., Biol. Pharm. Bull., 20, 315321 (1997).

12) Perrone C. E., Shao L., Williams G. M., Toxicol. Appl. Pharmacol., 150, 277-286 (1998).

13) Hashimoto F., Taira S., Hayashi H., Biol. Pharm. Bull., 21, 11421147 (1998).

14) Goll V., Alexandre E., Viollon-Abadie C., Nicod L., Jaeck D., Richert L., Toxicol. Appl. Pharmacol., 160, 21-32 (1999).

15) Hashimoto F., Taira S., Hayashi H., Biochem. Pharmacol., 59, 1203 $1210(2000)$.

16) Goll V., Viollon-Abadie C., Nicod L., Richert L., Hum. Exp. Toxicol., 19, 193-202 (2000).

17) Nemali M. R., Usuda N., Reddy M. K., Oyasu K., Hashimoto T., Osumi T., Rao M. S., Reddy J. K., Cancer Res., 48, 5316-5324 (1988).
18) Mendis-Handagama S. M., Watkins P. A., Gelber S. J., Scallen T. J., Zirkin B. R., Ewing L. L., Endocrinology, 127, 2947-2954 (1990).

19) Chance D. S., Wu S.-M., McIntosh M. K., Proc. Soc. Exp. Biol. Med., 208, 378-384 (1995).

20) King B. F., Histochemistry, 74, 115-121 (1982).

21) Matsuo H., Strauss J. F. III, Endocrinology, 135, 1135-1144 (1994).

22) Watson A. L., Skepper J. N., Jauniaux E., Burton G. J., Placenta, 19, 27-34 (1998).

23) Cohen B. I., Raicht R. F., Shefer S., Mosbach H., Biochim. Biophys. Acta, 369, 79-85 (1974)

24) Hayashi H., Takahata S., Arch. Biochem. Biophys., 284, 326-331 (1991).

25) Shiota Y., Ikeda M., Hashimoto F., Hayashi H., J. Biochem. (Tokyo), 134, 197-202 (2003).

26) Lewis M. P., Clements M., Takeda S., Kirby P. L., Seki H., Lonsdale L. B., Sullivan M. H. F., Elder M. G., White J. O., Placenta, 17, 137146 (1996).

27) Hashimoto F., Oguchi Y., Morita M., Matsuoka K., Takeda S., Kimura M., Hayashi H., Biochem. Pharm., 68, 313-321 (2004).

28) Kovacs W. J., Olivier L. M., Krisans S. K., Prog. Lipid Res., 41, 369 391 (2002).

29) Vahouny G. V., Canderbhan R., Noland B. J., Irwin D., Deniss P., Lambeth J. D., Scallen T. J., J. Biol. Chem., 258, 11731-11737 (1983).

30) Vahouny G. V., Dennis P., Chanderbhan R., Fiskum G., Noland B. J., Scallen T. J., Biochem. Biophys. Res. Commun., 122, 509-515 (1984).

31) Pfeifer S. M., Furth E. E., Ohba T., Chang Y. J., Rennert H., Sakuragi N., Billheimer J. T., Straus J. F. III, J. Steroid Biochem. Mol. Biol., 47, 167-172 (1993).

32) Tsuneoka M., Yamamoto A., Fujiki Y., Tashiro Y., J. Biochem. (Tokyo), 104, 560-564 (1988)

33) Keller G. A., Scallen T. J., Clarke D., Maher P. A., Krisans S. K., Singer S. J., J. Cell Biol., 108, 1353-1361 (1989).

34) van Amerongen A., van Noort M., van Beckhoven J. R., Rommerts F. F., Orly J., Wirtz K. W. A., Biochim. Biophys. Acta, 1001, 243-248 (1989).

35) Yokota S., Acta Histochem. Cytochem., 26, 263-273 (1993).

36) Yokota S., Fahimi H. D., Ann. N.Y. Acad. Sci., 386, 491- 494 (1982).

37) Laemlli U. K., Nature (London), 227, 680-685 (1970).

38) de Duve C., Pressman B. C., Gianetto R., Wattiaux R., Appelman F., Biochem. J., 60, 604-609 (1955).

39) Leighton F., Poole B., Beaufay H., Baudhuim P., Coffey L. W., Fowler S., de Duve C., J. Cell Biol., 37, 482-513 (1968).

40) Hayashi H., Suga T., J. Biochem. (Tokyo), 84, 513-520 (1978).

41) Wharton D. C., Tzagoloff A., Methods Enzymol., 10, 245-250 (1967).

42) Beaufay H., Amar-Costesec A., Feytmans E., Thines-Sempoux D., Wibo M., Berthet T., J. Cell Biol., 61, 188-200 (1974).

43) Lowry O. H., Rosebrongh N. J., Farr A. L., Randall R. J., J. Biol. Chem., 193, 265-275 (1951).

44) Hess R., Staubli W., Riess W., Nature (London), 208, 856-858 (1965).

45) Gorgas K., Anat. Embryol., 169, 261-270 (1984).

46) Roels F., Espeel M., Pauwels M., De Craemer D., Egberts H. J., van der Spek P., Gut, 32, 858-865 (1991).

47) Novikoff P. M., Novikoff A. B., J. Cell Biol., 53, 532-560 (1972).

48) Suzuki Y., Yamaguchi S., Orii T., Tsuneoka M., Tashiro Y., Cell Struct. Funct., 15, 301-308 (1991).

49) Magalhaes M. M., Magalhaes M. C., Microsc. Res. Tech., 36, 493502 (1997).

50) Olivier L. M., Krisans S. K., Biochim. Biophys. Acta, 1529, 89-102 (2000).

51) Kovacs W. J., Tape K. N., Shackelford J. E., Duan X., Kasumov T., Kelleher J. K., Brunengraber H., Krisans S. K., Hystochem. Cell Biol., 127, 273-290 (2007). 